\title{
Standardization of NAT for Blood-Borne Pathogens
}

\author{
Sally A. Baylis ${ }^{a} \quad$ Michael Chudy ${ }^{a} \quad$ C. Micha Nüblinga, b \\ ${ }^{a}$ Department of Virology, Paul-Ehrlich-Institut, Langen, Germany; \\ ${ }^{b}$ World Health Organization, Essential Medicines and Health Products Department, Geneva, Switzerland
}

\section{Keywords}

NAT · IVD · Standardization · WHO standards . International unit

\section{Summary}

Assays based on nucleic acid amplification technology (NAT) are increasingly used for screening of blood and for diagnosis or monitoring of patients. Both regulatory requirements for blood screening and international recommendations for the treatment of patients are based on common reference materials available globally for the standardization of NAT assays. World Health Organization International Standards (WHO ISs) and International Reference Panels (WHO IRPs) are primary reference materials. The characterization and manufacture of WHO reference materials as well as their evaluation is performed on behalf of the WHO by collaborating centers; their establishment is decided upon by the WHO Expert Committee on Biological Standardization (ECBS). The potency of the first WHO IS is defined by the 'international unit' (IU) which should be maintained upon replacement of the IS. The IU, unlike copy number or genome equivalent, is defined by the IS with a physical existence, is available worldwide, and allows traceability and comparability of results. The anticipated use of WHO ISs is the calibration of secondary standards or the validation of essential assay features, e.g. limit of detection.

(c) 2015 S. Karger GmbH, Freiburg

\section{Introduction}

Significant progress has been made in the last 20 years in the standardization of nucleic acid tests, including nucleic acid amplification-based techniques (NATs) for the detection of blood-borne pathogens. The driving force behind the standardization efforts was the transmission of diseases such as hepatitis and AIDS by blood products and blood components contaminated with viruses such as HCV and HIV, particularly by 'window period' donations tested negative by serological screening assays. The widespread implementation of NAT testing in blood donor screening, particularly for HCV, was facilitated by the availability of internationally recognized reference materials. These were used for defining assay features, e.g. analytical sensitivities, of different testing methods allowing comparison of results. The development of such reference materials or standards has not only helped drive improvements in blood safety, it has also harmonized assays designed for the diagnosis and monitoring of infectious diseases in the clinical setting as well. Furthermore, regulatory requirements for blood screening (e.g. minimal NAT sensitivity) or recommendations in treatment guidelines (e.g. threshold values) are dependent on common reference materials $[1,2]$.

Early quality control studies to monitor the performance of testing laboratories for the detection of HCV RNA by NAT assays demonstrated lack of sensitivity and specificity [3] and highlighted the importance of standardization. Such differences in assay sensitivity and specificity could, for example, result in the release of unsafe blood components or affect the timely availability of essential medicinal products, e.g., if discordant results were reported between manufacturers of plasma-derived products and the respective control laboratories. So the development of common standards became an urgent priority, and candidate standards were proposed and prepared concurrently at the National Institute for Biological Standards and Control (NIBSC) and the Central Laboratory of the Netherlands Red Cross Blood Transfusion Service $[4,5]$. In 1995, a World Health Organization (WHO) international work- 
ing group on 'Standardization of Genomic Amplification Techniques' (SoGAT) was established. The major aims of SoGAT were, and still are, to identify pathogens where NAT standardization is urgently required as well as to plan and co-ordinate collaborative studies for the development and evaluation of reference materials. In initial studies, dilutions of HCV viremic plasma were sent to collaborating laboratories and evaluated by assays in routine use. Reference materials, termed 'working reagents', were subsequently prepared based on the lowest concentration of diluted viremic plasma that was detected by the majority of participants [5]. Following this initial success, and with the requirement to introduce NAT testing for HCV RNA for blood and plasma, the first WHO International Standard (IS) HCV for NAT was developed [6]. Studies on HIV-1 had also demonstrated a need for assay standardization [7-9], and development of an IS for HIV-1 also became a priority [10], followed by other blood-borne viruses (parvovirus B19 (B19V), human cytomegalovirus (HCMV), Epstein-Barr virus (EBV), HAV, HBV, HDV, HEV, HIV-2) and parasites (Plasmodium falciparum, Toxoplasma gondii), including those of importance in transplantation and the clinical setting [11-18].

\section{Standardization of Genomic Amplification Techniques (SoGAT)}

The standardization work of SoGAT has continued successfully over the past two decades. Over the years, the initial focus on standardization of qualitative and quantitative NAT assays designed to detect or quantify blood safety-related pathogens was expanded to include the NAT detection of other clinically important pathogens where standardization had not been addressed, resulting in an establishment of further WHO ISs. The SoGAT meetings were held at least once a year with discussion of the results of collaborative studies and their interpretation prior to submission to the WHO Expert Committee on Biological Standardization (ECBS). More recently, meetings have been held every 1-2 years and have focused on replacement of existing ISs and the development of new reference materials being of use mainly in clinical microbiology settings. Extraordinary meetings are held occasionally in order to discuss specific projects in greater depth, as was done in 2007 in order to develop a genotype panel for B19V [19]. On this occasion, classification of new B19V variants, shortcomings in $\mathrm{B} 19 \mathrm{~V}$ assays and the implication on batch release testing were discussed, and how best develop genotype panels by identifying which parties were able to supply viremic plasma prior to undertaking studies to determine their suitability as reference materials [20].

\section{WHO International Standards}

Role of ISs

WHO ISs are biological materials of complex composition similar to actual clinical or blood donor specimens. The ISs represent measurement standards and are given an internationally agreed unitage, i.e. the international unit (IU), after evaluation in collaborative studies using a range of methods. In the case of the standards for NAT-based assays, the assigned unitages have usually reflected the mean potencies ('NAT detectable units') determined in the collaborative studies. The main functions of the ISs are the calibration of secondary standards (with potencies also assigned in IU), the validation of essential quality features of assays (e.g. detection limit) and to ensure uniform reporting of results based on the IU. The European Directive on in vitro diagnostic medical devices (IVD Directive) states that 'the traceability of values assigned to calibrators and/or control materials must be assured through ... available reference materials of a higher order' (Directive 98/79/ EC, Annex I: Essential Requirements), and IVD manufacturers must comply with this [21]. The WHO ISs are primary or 'higherorder' standards recognized globally. Furthermore, for the socalled 'high-risk IVDs' (designed for the detection or quantitation of HIV, HBV, HCV, or HTLV infection markers) the Common Technical Specifications of the IVD Directive request both the inclusion of WHO ISs in the performance evaluation and the reporting of test results in $\mathrm{IU} / \mathrm{ml}[22]$.

\section{Preparation of Candidate ISs}

The WHO ISs for NAT assays have typically been prepared from plasma from infected blood donors or patients, further diluted in pooled plasma and, similar to the samples, being tested in the laboratory. In some cases where, for example, donor or patient material has been unavailable in sufficient quantities, the pathogens have been derived in cell culture. Occasionally some pathogens have been diluted in buffered matrix, containing sugars and excipients such as albumin. The starting materials are pre-qualified to ensure that they contain the specific pathogen in sufficiently high titer, the strain is well detected and the intended final formulation performs across a range of NAT assays. Where it has been possible, the most prevalent pathogen genotypes have been selected for the development of ISs.

In order to distribute WHO ISs in a cost-effective manner, they are typically lyophilized. The materials are dispensed into vials or ampoules and, following lyophilization, are back-filled with nitrogen gas. Part of the pre-qualification process is to ensure that candidate ISs are stable, and in many cases lyophilization can help improve stability. Once a final formulation of the candidate IS has been found, the bulk material is filled into several thousand vials.

Some preparations have undergone heat inactivation to make processing and dispatch more straightforward; however, it is not always possible to sufficiently validate the inactivation process $[12$, 23]. The inactivation method should not affect detection of the pathogen. The plasma donations and diluents are tested for a range of other infectious markers to ensure, where possible, that other infectious agents are absent from the final formulation. Detailed information for the preparation, characterization, and establishment of ISs has been published by the WHO [24]. 


\section{Evaluation of Candidate ISs}

\section{International Collaborative Study}

Candidate preparations for WHO ISs are thoroughly characterized in international collaborative studies organized by one of the WHO Collaborating Centers. The participants of such studies include, for example, blood product manufacturers, kit producers, regulatory organizations as well as reference laboratories. Participation in studies is voluntary and without remuneration; efforts are made to include all different types of globally available assays, including in-house-developed tests, for the respective analytes. The panels distributed to the participants comprise different coded samples, including the candidate IS material, specimens that might be used as replacement ISs in the future as well as native samples where possible. In the study protocol, participants are often requested to test replicates of the neat and/or diluted materials and to report back the test results: quantitative values (e.g. 'copies/ml') within the linear range of quantitative assays, or positive or negative results obtained for end point dilution series analyzed in qualitative assays. The test results reported back are used for statistical calculation of the 'NAT-detectable units' contained in the different samples. This estimation takes into account assay-specific parameters like extraction volume, elution volume, and elution fraction used in the amplification reaction. The potency of the WHO IS, assigned in IU/ml is usually close to the mean 'NAT detectable units/ml' determined in the collaborative study across all assays. Harmonization of assay results are evaluated by using the candidate material as a common calibrator between the different assays, with suitable reference materials introducing a more consistent reporting of assays in IU compared to the previous reporting in 'copies', 'genome equivalents' etc. based on different calibrator materials used by different manufacturers of commercial assays or also laboratories with in-house-developed tests, as it is true, e.g. for diagnosis of HEV [25]. Another example for harmonization of results is seen with HCMV NAT assays when, for example, results from the AD169 strain grown in cell culture were expressed relative to the eventual IS prepared from cultured Merlin strain [17].

\section{Commutability}

The candidate material is further analyzed for its commutability to ensure its performance in different assays is equivalent to routine samples such as patient or blood donor specimens [26, 27]. For example, non-commutability may be caused by matrix differences between the reference material and routine specimens. The more similar the composition of the WHO IS to the routine samples, the less likely are potential issues of non-commutability. With the usual choice of negative human plasma as matrix for the WHO ISs for NAT assays, commutability issues have been rare for this kind of material. In the case of non-commutability of a common calibrator, assay harmonization for clinical specimens would not be achieved, and it may even worsen agreement between assays as has been reported for HCMV NATs and a commercial standard material [28]. It is now expected that WHO Collaborating Centers address commutability of new reference preparations in studies in- volving routine specimens and selected assays that at least represent those most widely used [29]. However, conclusions can only be drawn about the assays evaluated in such studies. Further attempts to increase the commutability database is the inclusion of WHO ISs or candidate materials in external quality assurance (EQA) schemes, an approach which can potentially allow the comparison of more assays.

\section{Characterization}

Batches of WHO ISs are evaluated for a range of biological, physical, and physicochemical characteristics. These include the variation of the filling process (volume dispensed), the homogeneity of the analyte after filling and lyophilization, the effects of lyophilization on the potency of the analyte as well as an analysis of its stability which may be affected by levels of residual moisture and oxygen present in the final vials.

The filling variation is determined by weighing of selected vials prior to lyophilization, typically the variation observed for biological reference materials is $<1 \%$. For the lyophilized preparations, residual moisture levels are usually in the range of $1-2 \%(\mathrm{w} / \mathrm{w})$ for plasma-based preparations and consistent with WHO recommendations [24].

After lyophilization, it has been observed that there may be a loss of titer (in the order of $0.3-1.0 \log _{10}$ ), particularly for some of the RNA viruses. This loss of titer may be caused by disintegration of a fraction of virus particles during lyophilization; in the case of DNA viruses this effect is less pronounced. The scientific principles behind this phenomenon are currently not well understood. However, it is part of the qualification process for lyophilized preparations to confirm across different technologies a similar relative drop, by direct comparison with the unprocessed bulk samples. By this approach the potential introduction of a bias based on the lyophilization step can be excluded.

Whilst WHO ISs are not assigned a shelf life, prior to establishment, the stability of the analyte at different temperatures (usually ranging from -20 to $+45^{\circ} \mathrm{C}$ ) is determined in order to reflect the recommended storage temperature (usually $-20^{\circ} \mathrm{C}$ ) and worldwide transport at ambient temperatures. Stability monitoring continues throughout the life of the product.

\section{Selection and Establishment of WHO ISs}

Based on the need for standardization, identified by the scientific and medical community worldwide, the prioritization of standardization projects is agreed between WHO and the three WHO Collaborating Centers in the fields of blood and in vitro diagnostic devices. These three WHO Collaborating Centers are: the NIBSC (Potters Bar, UK), the US Food and Drug Administration, Center for Biologics Evaluation and Research (FDA, CBER; Silver Spring, MD, USA), and the Paul-Ehrlich-Institut (PEI, Langen, Germany). There are regular meetings between these parties where requests for standardization from WHO member states, industry, and the scientific community are assessed. The WHO ECBS is 
Table 1. Current WHO ISs for NAT for blood-borne pathogens

\begin{tabular}{|c|c|c|c|}
\hline Preparation (unitage) & Standard (code number) & $\begin{array}{l}\text { Year of } \\
\text { establishment }\end{array}$ & Material \\
\hline EBV DNA $(5,000,000$ IU/vial $)$ & 1 st IS $(09 / 260)$ & 2011 & $\begin{array}{l}\text { type } 1 \text { EBV B95- } 8 \text { strain cultured, diluted in buffer / } \\
\text { human serum albumin / trehalose }\end{array}$ \\
\hline HAV RNA (27,000 IU/vial) & 2nd IS (00/562) & 2013 & genotype Ia viremic human plasma \\
\hline HCMV DNA $(5,000,000$ IU/vial $)$ & 1st IS $(09 / 162)$ & 2010 & $\begin{array}{l}\text { genotype } 1 \text { Merlin strain, cultured, diluted in buffer/ } \\
\text { human serum albumin/trehalose }\end{array}$ \\
\hline HBV DNA (425,000 IU/vial) & 3rd IS (10/264) & 2011 & genotype A, HBsAg subtype adw2 viremic human plasma \\
\hline HCV RNA (130,000 IU/vial) & 4 th IS $(06 / 102)$ & 2011 & genotype la viremic human plasma \\
\hline HDV RNA $(287,500 \mathrm{IU} / \mathrm{ml})$ & 1st IS (7657/12) & 2013 & genotype 1 viremic human plasma \\
\hline HEV RNA (125,000 IU/vial) & 1st IS $(10 / 6329)$ & 2011 & genotype 3 a viremic human plasma \\
\hline HIV-1 RNA (185,000 IU/vial) & 3rd IS (10/152) & 2011 & $\begin{array}{l}\text { subtype B isolate cultured, heat inactivated, } \\
\text { diluted in human plasma }\end{array}$ \\
\hline HIV-2 RNA (1,000 IU/vial) & 1st IS $(08 / 150)$ & 2009 & $\begin{array}{l}\text { genotype A CAM2 strain cultured, heat inactivated, } \\
\text { diluted inhuman plasma }\end{array}$ \\
\hline B19V DNA (705,000 IU/vial) & 3rd IS (12/208) & 2013 & genotype 1 viremic human plasma \\
\hline $\begin{array}{l}\text { P. falciparum DNA } \\
\qquad(500,000,000 \mathrm{IU} / \text { vial })\end{array}$ & 1st IS $(04 / 176)$ & 2006 & parasitemic human blood \\
\hline $\begin{array}{l}\text { T. gondii DNA } \\
\qquad(500,000 \mathrm{IU} / \text { vial })\end{array}$ & 1st IS $(10 / 242)$ & 2014 & $\begin{array}{l}\text { T. gondii tachyzoites obtained from infected mice, } \\
\text { diluted in buffer/trehalose }\end{array}$ \\
\hline
\end{tabular}

commissioned by the WHO to establish detailed recommendations and guidelines for the manufacturing, licensing, and control of biologicals, including blood products and related in vitro diagnostic tests. Members of the ECBS are scientists from national control agencies, academia, research institutes, public health bodies, and the pharmaceutical industry, acting as individual experts, and not as representatives of their respective organizations or employers. The decisions and recommendations of the ECBS are based entirely on scientific principles and public health considerations. The ECBS meets annually, reviews new proposals for standardization projects submitted for endorsement, and establishes new WHO ISs or replacement preparations where existing standard stocks are near depletion. For new WHO ISs for IVDs, the need for standardization in the respective diagnostic field and the effect on assays after harmonization, as demonstrated in the collaborative studies, are crucial. The ECBS agrees the assignment of the proposed potencies to the WHO ISs.

\section{Established WHO ISs}

Several WHO ISs for blood-borne pathogens have been established for NAT assays; the current standards are shown in table 1. The ISs include standards initially developed for the field of blood safety: HCV, HIV-1/2, HBV, B19V, HAV, P. falciparum. Other ISs have been developed that are of importance in transplantation; these include HCMV, EBV, HEV, and more recently T. gondii.
Whilst clinically important, HCMV and HEV are also of a concern in transfusion medicine. An IS for HDV - a defective virus reliant on HBV - has also been established. The data obtained in the collaborative studies are summarized in reports accessible via WHO webpage [18].

\section{Replacement of WHO ISs}

WHO ISs are prepared in batches of several thousands of vials. Though distribution is restricted to a few vials (e.g. 5 vials) per laboratory and per year, stocks will inevitably be depleted after some time and a replacement prepared. For replacement of WHO ISs, the continuity of the IU should be maintained and should be as similar as possible to that defined by the previous IS. This is achieved by careful selection of the most similar analyte (e.g. same virus genotype as in the WHO IS to be replaced), a similar matrix, and by direct comparison of the WHO IS with its candidate replacement preparation across a variety of different assays in a collaborative study. Another option is the choice of the same source material (kept at $-80^{\circ} \mathrm{C}$ ) for different generations of WHO ISs for the same analyte. This approach has been followed for the different WHO ISs for HBV DNA using the Eurohep material as common stock. Suitable replacement preparations are typically characterized by low variation of absolute as well as relative potency when compared against the predecessor by using different assays and technologies $[23,30-32]$. In some cases, potential candidate replace- 
Table 2. WHO standards which have been replaced

\begin{tabular}{|c|c|c|c|c|c|}
\hline Preparation & $\begin{array}{l}\text { Standard } \\
\text { (code number) }\end{array}$ & $\begin{array}{l}\text { Year of } \\
\text { establishment }\end{array}$ & Material & $\begin{array}{l}\text { Unitage, } \\
\text { IU/vial }\end{array}$ & Reference \\
\hline \multirow[t]{2}{*}{ HAV RNA } & 1st IS $(00 / 560)$ & 2003 & viremic human plasma, genotype Ia diluted in pooled plasma. & 50,000 & {$[16]$} \\
\hline & 2nd IS $(00 / 562)$ & 2013 & $\begin{array}{l}00 / 560 \text { and } 00 / 562 \text { were prepared from the same single donation } \\
\text { and the same diluent and lyophilized separately }\end{array}$ & 27,000 & {$[47]$} \\
\hline \multirow[t]{2}{*}{ HBV DNA } & 1st IS $(97 / 746)$ & 1999 & viremic human plasma - Eurohep R1; genotype A, HBsAg subtype & 500,000 & {$[14]$} \\
\hline & 3rd IS $(10 / 264)$ & 2011 & $\begin{array}{l}\text { from the same original bulk but lyophilized separately; } 10 / 264 \text { was } \\
\text { prepared using the same strain with new pooled plasma diluent }\end{array}$ & 425,000 & {$[48]$} \\
\hline \multirow[t]{3}{*}{ HCV RNA } & 1st IS $(96 / 790)$ & 1997 & HCV genotype la viremic human plasma (anti-HCV positive) & 50,000 & {$[6]$} \\
\hline & 2nd IS (96/798) & 2003 & $\begin{array}{l}\text { diluted in pooled human cryosupernatant. } 96 / 790 \text { and } 96 / 798 \text { were } \\
\text { prepared from the same original bulk but lyophilized separately }\end{array}$ & 50,000 & {$[33]$} \\
\hline & 3rd IS $(06 / 100)$ & 2007 & HCV genotype la viremic human plasma (anti-HCV negative, & 77,440 & {$[32]$} \\
\hline \multirow[t]{3}{*}{ HIV-1 RNA } & 1st IS $(97 / 656)$ & 1999 & $\begin{array}{l}\text { HIV-1 subtype B viremic human plasma diluted in pooled human } \\
\text { cryosupernatant. }\end{array}$ & $100,000^{*}$ & {$[10]$} \\
\hline & 2nd IS $(97 / 650)$ & 2006 & cultured subtype B isolate diluted in pooled human cryosupernatant & $363,078^{*}$ & {$[23]$} \\
\hline & 3rd IS (10/152) & 2011 & $\begin{array}{l}\text { cultured and heat-inactivated subtype B isolate (the same strain as } \\
97 / 650 \text { ) diluted in human plasma }\end{array}$ & $185,000^{*}$ & {$[49]$} \\
\hline \multirow[t]{3}{*}{ B19V } & 1st IS $(99 / 800)$ & 2004 & B19V genotype 1a viremic human plasma diluted in pooled plasma; & 500,000 & {$[15]$} \\
\hline & 2nd IS $(99 / 802)$ & 2008 & $\begin{array}{l}99 / 800 \text { and } 99 / 802 \text { were prepared from the same original bulk but } \\
\text { lyophilized separately }\end{array}$ & 500,000 & {$[31]$} \\
\hline & 3rd IS $(12 / 208)$ & 2013 & B19V genotype 1 viremic human plasma diluted in pooled plasma & 705,000 & {$[50]$} \\
\hline
\end{tabular}

${ }^{\star}$ The HIV-1 IS preparations are reconstituted in $1 \mathrm{ml}$ of water; all other preparations are reconstituted in $0.5 \mathrm{ml}$ of water. The concentration of the respective ISs is shown per vial and not per $\mathrm{ml}$.

ment preparations will already have been characterized in the collaborative study where the original IS was established. Several established ISs for NAT-based assays have already been replaced, and these are listed in table 2. For example, in 1997, the very 1st WHO IS established for NAT-based assays was for HCV RNA (code number 96/790), [6] and replaced by the 2nd IS (96/798) in 2003 [33]; both preparations were derived from the same original HCV genotype 1a plasma donation. The 3rd IS for HCV (06/100) was prepared using new HCV genotype 1a-positive plasma [32], and has subsequently been replaced by a second batch of this new material with the establishment of the 4th IS (06/102) [34].

\section{WHO International Reference Panels}

In addition to WHO ISs, WHO International Reference Panels (WHO IRPs) are established by ECBS, following similar principles for the establishment of WHO ISs. In contrast to WHO ISs, the WHO IRPs are comprised of different panel members often reflecting different variants of the same analyte, e.g. different virus genotypes with distinct global distribution $[19,35,36]$. The design and manufacture of WHO IRPs involves worldwide collection of candidate specimens of sufficient volume and concentration as well as their initial characterization, lyophilization, and subsequent evaluation in a collaborative study. There is no unitage (e.g. IU, copies etc.) assigned to individual panel members. However, as for WHO ISs the data obtained in the collaborative study are available on the WHO website [18]. These include the results for the individual panel members obtained by different assays. While WHO ISs are used for calibration of secondary standards or for validation of essential assay features, e.g. detection limit, IRPs are used to check for consistent detection or quantitation across variants of the analyte, e.g. across virus genotypes. IRPs have been used by IVD manufacturers and by IVD regulators to check assay performance. Indeed, there are examples where deficiencies of individual NAT assays, have been improved based on results of IRPs, e.g. with the HIV-1 subtype panel (non-detection of HIV-1 subtype O) or the B19V genotype panel (absence of detection as well as under-quantitation of genotypes 2 or 3 ) $[19,35]$. Table 3 shows the current WHO IRPs available for NAT assays.

\section{Secondary Standards}

WHO ISs are only available in limited amounts and are intended for use primarily for the calibration (in IU) of secondary standards. Secondary standards include regional standards, e.g. materials provided by the European Directorate for the Quality of 
Table 3. Current WHO IRPs for NAT for blood-borne pathogens

\begin{tabular}{lllll}
\hline Panels (number of members) & Standard (code number) & $\begin{array}{l}\text { Year of } \\
\text { establishment }\end{array}$ & Material & Reference \\
\hline HBV genotypes (15) & 1st IRP (5086/08) & 2009 & viremic plasma donations; HBV genotypes A-G & [36] \\
\hline HIV-1 subtypes (10) & 2nd IRP (12/224) & 2012 & $\begin{array}{l}\text { cultured and heat-inactivated HIV-1 subtypes A, B, } \\
\text { C, D, AE, F, G, AG-GH, N and O diluted in human } \\
\text { plasma (strains are identical to the 1st IRP) }\end{array}$ & [51] \\
\hline $\begin{array}{l}\text { HIV-1 circulating recombinant } \\
\text { forms (10) }\end{array}$ & 1st IRP (13/214) & 2013 & $\begin{array}{l}\text { cultured and heat-inactivated HIV-1 CRFs and } \\
\text { subtype variants diluted in human plasma }\end{array}$ \\
\hline $\begin{array}{l}\text { B19V genotypes (4) } \\
\text { [st IRP (09/110; }\end{array}$ & 2009 & $\begin{array}{l}\text { viremic plasma donations; B19V genotypes 1, 2, 3a } \\
\text { and negative plasma }\end{array}$ & \\
\hline
\end{tabular}

Medicines (EDQM). The EDQM provides so-called Biological Reference Preparations (BRPs) for a variety of analytes. These BRPs include analytes for which mandatory testing is defined in the European Pharmacopoeia, e.g. HCV RNA or B19V DNA for plasma for fractionation. BRPs are calibrated against the WHO IS in a collaborative study similar to those performed when establishing the WHO ISs. The BRPs are subsequently assigned a potency in IU relative to the WHO IS [37]. BRPs are provided as a common reference material both to Official Medicines Control Laboratories (OMCLs) and to manufacturers of biological medicines. BRPs are also used in the context of proficiency testing programs organized by EDQM.

Another source for secondary standards may be national regulatory authorities. As an example, the PEI in Germany provides lyophilized secondary standards with potency assigned in IU - socalled 'PEI Reference Materials' - which are available to IVD manufacturers, blood banks, and test kit users. Some of the PEI Reference Materials have been calibrated together with other secondary standards in international collaborative studies [38].

Test kit manufacturers usually calibrate their own in-house standards against the primary reference material, i.e., the WHO IS. These in-house standards are used for calibrating the assays in $\mathrm{IU} / \mathrm{ml}$, for determining assay features and for quality control purposes. Other secondary standards calibrated against the WHO IS include working reagents for use in routine assays, for example, as day-to-day run controls, allowing independent monitoring of test kit performance aside from controls provided by the kit manufacturer $[38,39,40]$.

\section{Synthetic versus Biological Reference Preparations}

There have been efforts to circumvent the complexity of biological standards for NAT assays by the use of synthetic nucleic acids. In this context the definition of synthetic standards includes chemically synthesized nucleic acids, in vitro transcribed RNAs, or plasmids purified from bacteria. These materials are in principle traceable to metrological SI units (e.g. mol) and may be consistently manufactured and characterized (and replaced) in an envi- ronment fulfilling the requirements of a metrological reference system [41]. However, commutability of synthetic standards may be an issue because these materials are often not readily compatible with usual matrixes, e.g. human plasma. The WHO ISs for NAT assays are derived from patient materials and/or cell culture and contain widely intact pathogens, e.g. virus particles, better reflecting blood donor or patient specimens. Another disadvantage of synthetic standards is that they fail to control for the nucleic acid extraction step prior to amplification, the most critical and variable step of the NAT process. The suitability of synthetic standards for controlling the amplification reaction of different HCV NAT assays has been shown in a study organized by different manufacturers, however, without real evidence for superiority when compared to well-characterized biological standards [42]. Despite these limitations as primary standards, (bio-)synthetic materials can be of value in assay calibration by test kit manufacturers and may play a greater role in the future as ways evolve in the replacement of ISs.

\section{Standards Currently under Development}

A number of new standardization projects have been agreed between WHO and the three WHO Collaborating Centers which should lead to the establishment of further ISs in the near future. These projects include candidate ISs for NAT assays for 'emerging' pathogens such as chikungunya virus, dengue virus, West Nile virus as well as Ebola virus. However, further projects in the transplantation field include candidate ISs for the polyomaviruses BK and JC, HHV-6, and adenovirus. For some viruses, WHO IRPs are also in development, including one for HEV genotypes that reflect the global disease burden.

\section{NAT Quality Assurance}

For the consistent application of NAT assays, the use of reference materials are not the only consideration to ensure standardization of results, but there are many other aspects of quality assurance that must be taken into account. Operators should be trained 
in technical procedures and specific assays, be competent in the interpretation of data, and are able to undertake remedial/corrective actions where necessary. Controls for interference/inhibition as well as positive (working reagents or run controls) and negative controls to ensure test validity criteria are met. Quality assurance measures should include the use of standard operating procedures and associated documentation, correct handing of samples to ensure appropriate storage and traceability, calibration of equipment, designated laboratories, and the use of pre-qualified reagents [43]. It is well recognized that participation in EQA schemes also help to maintain robust assay implementation and ensure early identification of possible non-conformities [16, 45, 46].

\section{Conclusions}

In the 1990s, mandatory testing of biological products by NAT screening was introduced, even though at the time such techniques were relatively new with only a few commercially available assays. NAT assays used for safety testing of blood donations and plasma for fractionation included in-house-developed assays and commercial assays often modified to fit this purpose. The international SoGAT working group was founded in 1995 because of the urgent need to have a common basis for the comparison of the results provided by different assays. This open forum has had a major influence on the current high level of standardization of NAT assays in the fields of blood screening and clinical diagnosis of blood-borne pathogens. Since the early discussions of standardization of NAT, many commercial assays have been developed for different platforms, including highly automated systems that are capable of processing hundreds of samples per day. The development of real-time PCR has improved quantitation compared to end point detection methods. This rapid development was supported by reference materials prepared on behalf of the WHO which are globally available and ensure common reporting in IU. The development of new methods such as digital PCR will help better define IU to copy number ratios, and efforts should be made, where possible, to better understand the relationship with infectious units, in order to enable, e.g., risk assessments for plasma-derived medicinal products. This biological standardization needs to be extended to fields other than blood screening and to clinically important blood-borne pathogens. The use of well-characterized biological preparations that mimic routine clinical samples, both in relation to features of the analyte as well as of the test matrix, is a prerequisite. The harmonization of assays is indispensable by ensuring that through common reporting in IU harm to patients is avoided as is unnecessary loss of essential biological products.

\section{Disclosure Statement}

The authors declare no conflict of interest.

\section{References}

1 Paul-Ehrlich-Institut: Stufenplan: Bekanntmachung über die Ergebnisse des Stufenplanverfahrens zur Verminderung des Risikos von Hepatitis B-, Hepatitis Cund HIV Infektionen bei Empfängern von Erythrozytenkonzentraten (Bundesanzeiger Nr. 63 vom 04.04.1997, S. 4477). Bundesanzeiger 1989;53:3835.

2 Albertia A, Caporaso N: HBV therapy: Guidelines and open issues. Dig Liver Dis 2011;43(suppl 1):S57-63.

$\checkmark 3$ Zaaijer HL, Cuypers HT, Reesink HW, Winkel IN, Gerken G, Lelie PN: Reliability of polymerase chain reaction for detection of hepatitis C virus. Lancet 1993; 341:722-724.

4 Damen M, Cuypers HT, Zaaijer HL, Reesink HW, Schaasberg WP, Gerlich WH, Niesters HG, Lelie PN: International collaborative study on the second EUROHEP HCV-RNA reference panel. J Virol Methods 1996;58:175-185.

5 Saldanha J, Minor P: Collaborative study to assess the suitability of an HCV RNA reference sample for detection of an HCV RNA in plasma pools by PCR. Vox Sang 1996;703:148-151.

6 Saldanha J, Lelie N, Heath A: Establishment of the first international standard for nucleic acid amplification technology (NAT) assays for HCV RNA. WHO Collaborative Study Group. Vox Sang 1999;76:149-158.

7 Bootman JS, Kitchin PA: An international collaborative study to assess a set of reference reagents for HIV-1 PCR. J Virol Methods 1992;37:23-41.

8 Bootman JS, Kitchin PA: Reference preparations in the standardisation of HIV-1 PCR - an international collaborative study. J Virol Methods 1994;49:1-8.
Heath $\mathrm{AB}$, Hughes P, Holmes $\mathrm{H}$ : An international collaborative study on the detection of an HIV-1 genotype B field isolate by nucleic acid amplification techniques. J Virol Methods 1999;78:21-34.

10 Holmes H, Davis C, Heath A, Hewlett I, Lelie N: An international collaborative study to establish the 1st international standard for HIV-1 RNA for use in nucleic acid-based techniques. J Virol Methods 2001;92: $141-150$.

11 Baylis SA, Blümel J, Mizusawa S, Matsubayashi K, Sakata H, Okada Y, Nübling CM, Hanschmann KM; HEV Collaborative Study Group: World Health Organization International Standard to harmonize assays for detection of hepatitis E virus RNA. Emerg Infect Dis 2013;19:729-735.

12 Holmes H, Berry N, Heath A, Morris C: Preparation and evaluation of the 1st international standard for the quantitation of HIV-2 RNA in plasma. J Virol Methods 2001;175:246-252.

13 Padley DJ, Heath AB, Sutherland C, Chiodini PL, Baylis SA; Collaborative Study Group: Establishment of the 1st World Health Organization International Standard for Plasmodium falciparum DNA for nucleic acid amplification technique (NAT)-based assays. Malar J 2008;7:139.

14 Saldanha J, Gerlich W, Lelie N, Dawson P, Heermann K, Heath A; WHO Collaborative Study Group: An international collaborative study to establish a World Health Organization international standard for hepatitis B virus DNA nucleic acid amplification techniques. Vox Sang 2001;80:63-71.
5 Saldanha J, Lelie N, Yu MW, Heath A; B19 Collaborative Study Group: Establishment of the first World Health Organization International Standard for human parvovirus B19 DNA nucleic acid amplification techniques. Vox Sang 2002;82:24-31.

16 Saldanha J, Heath A, Lelie N, Pisani G, Yu MY; Collaborative Study Group: A World Health Organization International Standard for hepatitis A virus RNA nucleic acid amplification technology assays. Vox Sang 2005;89:52-58.

17 World Health Organization: Collaborative Study to Evaluate the Proposed 1st WHO International Standard for Human Cytomegalovirus (HCMV) for Nucleic Acid Amplification (NAT)-Based Assays. WHO/BS/10.2138. 2010. http://whqlibdoc.who.int/hq/2010/WHO_BS_ 10.2138_eng.pdf (last accessed June 15, 2015).

18 World Health Organization: WHO International Biological Reference Preparations. Blood products and related substances: Blood safety. www.who.int/ bloodproducts/catalogue/Safe2015.pdf (last accessed June 15, 2015).

19 Baylis SA, Ma L, Padley DJ, Heath AB, Yu MW; Collaborative Study Group: Collaborative study to establish a World Health Organization International genotype panel for parvovirus B19 DNA nucleic acid amplification technology (NAT)-based assays. Vox Sang 2012;102:204-211.

20 Baylis SA: Standardization of nucleic acid amplification technique (NAT)-based assays for different genotypes of parvovirus B19: a meeting summary. Vox Sang 2008;94:74-80. 
21 European Commission: Directive 98/79/EC of the European Parliament and of the Council of 27 October 1998 on in vitro diagnostic medical devices. Official Journal of the European Union 1998;L 331/1-L331/37.

22 European Commission: Commission Decision of 3 February 2009 amending Decision 2002/364/EC on common technical specifications for in vitro-diagnostic medical devices (2009/108/EC). Official Journal of the European Union 2009;L39/34-L39/49.

23 Davis C, Berry N, Heath A, Holmes H: An international collaborative study to establish a replacement World Health Organization International Standard for human immunodeficiency virus 1 RNA nucleic acid assays. Vox Sang 2008;95:218-225.

24 World Health Organization: Recommendations for the preparation, characterization and establishment of international and other biological reference standards (revised 2004). WHO Technical Report Series 2006; 932:73-131. www.who.int/immunization_standards/ vaccine_reference_preparations/TRS932Annex\%202_ Inter\%20_biol\%20ef\%20standards\%20rev2004.pdf (last accessed June 15, 2015).

-25 Baylis SA, Hanschmann KM, Blümel J, Nübling CM; HEV Collaborative Study Group: Standardization of hepatitis E virus (HEV) nucleic acid amplification technique-based assays: an initial study to evaluate a panel of HEV strains and investigate laboratory performance. J Clin Microbiol 2011;49:1234-1239.

26 Miller WG, Myers GL, Rej R: Why commutability matters. Clin Chem 2006;52:553-554.

27 Vesper HW, Miller WG, Myers GL: Reference materials and commutability. Clin Biochem Rev 2007;28: 139-147.

28 Hayden RT, Shahbazian MD, Valsamakis A, Boonyaratanakornkit J, Cook L, Pang XL, Preiksaitis JK, Schönbrunner ER, Caliendo AM: Multicenter evaluation of a commercial cytomegalovirus quantitative standard: effects of commutability on interlaboratory concordance. J Clin Microbiol. 2013;51:3811-3817.

29 World Health Organization: WHO Consultation on Commutability of WHO Biological Reference Preparations for In Vitro Detection of Infectious Markers. WHO Headquarters, Geneva, 18-19 April, 2013. www. who.int/bloodproducts/norms/BS_2230_Addendum1_ Commutability.pdf?ua=1 (last accessed June 15, 2015).

30 Baylis SA, Heath AB, Chudy M, Pisani G, Klotz A Kerby S, Gerlich W: An international collaborative study to establish the 2nd World Health Organization International Standard for hepatitis B virus DNA nucleic acid amplification technology-based assays. Vox Sang 2008;94:358-362.

31 Baylis SA, Chudy M, Blümel J, Pisani G, Candotti D, José M, Heath AB: Collaborative study to establish a replacement World Health Organization International Standard for parvovirus B19 DNA nucleic acid amplification technology (NAT)-based assays. Vox Sang 2010;98:441-446.
32 Baylis SA, Heath AB; Collaborative Study Group: World Health Organization collaborative study to calibrate the 3rd International Standard for Hepatitis C virus RNA nucleic acid amplification technology (NAT)-based assays. Vox Sang 2011;100:409-417.

33 Saldanha J, Heath A, Aberham C, Albrecht J, Gentili G, Gessner M, Pisani G: World Health Organization collaborative study to establish a replacement WHO international standard for hepatitis $\mathrm{C}$ virus RNA nucleic acid amplification technology assays. Vox Sang 2005; 88:202-204.

34 Fryer JF, Heath AB, Wilkinson DE, Minor PD: Collaborative Study to Evaluate the Proposed 4th WHO International Standard for Hepatitis C Virus (HCV) for Nucleic Acid Amplification Technology (NAT)Based Assays. 2011;WHO/BS/2011.2173.

35 Holmes H, Davis C, Heath A: Development of the 1st International Reference Panel for HIV-1 RNA genotypes for use in nucleic acid-based techniques. J Virol Methods 2008;154:86-91.

36 Chudy M, Hanschmann KM, Kress J, Nick S, Campos R, Wend U, Gerlich W, Nübling CM: First WHO International Reference Panel containing hepatitis B virus genotypes A-G for assays of the viral DNA. J Clin Virol 2012;55:303-309.

37 Nübling CM, Daas A, Buchheit KH: Collaborative study for establishment of a European Pharmacopoei Biological Reference Preparation (BRP) for B19 virus DNA testing of plasma pools by nucleic acid amplification technique. Pharmeuropa Bio 2004;2003:27-34.

38 Saldanha J, Heath A, Lelie N, Pisani G, Nübling M, Yu M: Calibration of HCV working reagents for NAT assays against the HCV international standard. The Collaborative Study Group. Vox Sang 2000;78:217-224.

39 Davis C, Heath A, Best S, Hewlett I, Lelie N, Schuurman R, Holmes H: Calibration of HIV-1 working reagents for nucleic acid amplification techniques against the 1st international standard for HIV-1 RNA. J Virol Methods 2003;107:37-44.

40 Saldanha J, Minor P: Collaborative study to assess the suitability of a proposed working reagent for human parvovirus B19 DNA detection in plasma pools by gene amplification techniques. B19 Collaborative Study Group. Vox Sang 1997;734:207-211.

41 International Organization for Standardization: ISO 17511:2003(en): In vitro Diagnostic Medical Devices Measurement of quantities in Biological Samples Metrological traceability of Values assigned to Calibrators and Control Materials. www.iso.org/obp/ui/\#iso:std: iso:17511:ed-1:v1:en (last accessed June 15, 2015).
42 Madej RM, Davis J, Holden MJ, Kwang S, Labourier E, Schneider GJ: International standards and reference materials for quantitative molecular infectious disease testing. JMol Diagn 2010;12:133-143.

43 Chudy M, Hewlett I, Saldanha J, Bianco C, Conrad AJ, Gierman T, Heldebrant C, Rautmann GG, Roth WK, Stramer S, Weimer T, Whitaker B, Zerlauth G; NAT Task Force Group: Technical considerations for the performance of Nucleic acid Amplification Technology (NAT). Biologicals 2003;31:153-159.

44 Gentili G, Pisani G, Saldanha J, Cristiano K, Wirz M, Bisso GM, Mele C; EQA Participants: High proficiency in detecting the six major hepatitis $\mathrm{C}$ virus genotypes of laboratories involved in testing plasma by nucleic acid amplification technology. Vox Sang 2003;85:114-116.

45 Best SJ, Gust AP, Johnson EIM, McGavin CH, Dax E: Quality of human immunodeficiency virus viral load testing in Australia. J Clin Microbiol 2000;38:40154020 .

46 Schirm J, van Loon AM, Valetnine-Thon E, Klapper P, Reid J, Cleator G: External quality assessment program for qualitative and quantitative detection of hepatitis $\mathrm{C}$ virus RNA in diagnostic virology. J Clin Microbiol 2002;40:2973-2980.

47 Fryer JF, Heath AB, Morris CL, Collaborative Study Group: Collaborative Study to Evaluate the Proposed 2nd WHO International Standard for Hepatitis A Virus (HAV) for Nucleic Acid Amplification Technology (NAT)-Based Assays. 2013;WHO/BS/2013.2225.

48 Fryer JF, Heath AB, Wilkinson DE: Collaborative Study to Evaluate the Proposed 3rd WHO International Standard for Hepatitis B Virus (HBV) for Nucleic Acid Amplification Technology (NAT)-Based Assays. 2011;WHO/BS/2011.2170

49 Morris CL, Heath AB: International Collaborative Study to Establish the 3rd WHO International Standard for HIV-1 NAT Assays. 2011;WHO/BS/2011.2178

50 FryerJF, Heath AB, Morris CL, Collaborative Study Group: Collaborative Study to Evaluate the Proposed 3rd WHO International Standard for Parvovirus B19 (B19V) for Nucleic Acid Amplification Technology (NAT)-Based Assays. 2013;WHO/BS/2013.2224

51 Morris CL, Wigglesworth E, Heath AB: Report on an International Collaborative Study to Establish the 2nd WHO International Subtype Reference panel for HIV-1 NAT Assays. 2012;WHO/BS/2012.2209

52 Morris CL, Wigglesworth E, Heath AB: Report on an International Collaborative Study to Establish the 1st WHO International Reference Panel for HIV-1 Circulating Recombinant Forms for NAT Assays. 2013; WHO/BS/2013.2226 